\title{
EKSPLORASI KANDUNGAN PIGMEN DAN ALGINAT DARI RUMPUT LAUT COKLAT UNTUK PROSES PEWARNAAN KAIN SUTERA
}

\author{
EXPLORATION PIGMENTS AND ALGINATES CONTENT OF BROWN \\ SEAWEED FOR COLORING PROCESS ON SILK FABRIC
}

\author{
Rifaida Eriningsih, Rini Marlina, Theresia Mutia, Arif Wibi Sana, Anna Titis \\ Balai Besar Tekstil, Jalan Jenderal Ahmad Yani No. 390 Bandung \\ E-mail: texirdti@bdg.centrin.net.id
}

Tanggal diterima: 14 Agustus 2014, direvisi: 22 September 2014, disetujui terbit: 24 Oktober 2014

\begin{abstract}
ABSTRAK
Eksplorasi pigmen dan alginat dari rumput laut coklat dimaksudkan untuk mengekstraksi pigmen dari rumput laut coklat dan residunya diekstraksi kandungan alginatnya untuk proses pewarnaan pada kain sutera. Hasil ekstraksi pigmen rumput laut coklat teridentifikasi sebagai zat warna mordan asam yang memberikan warna alami yang dapat menghasilkan celupan pada kain sutera dengan ketahanan luntur warna terhadap pencucian, gosokan, keringat dan sinar dengan nilai baik. Berdasarkan analisis gugus fungsi dari rumput laut yang telah diekstraksi pigmennya menunjukkan bahwa kandungan alginatnya tidak ikut terekstraksi dan dapat diekstraksi lanjut. Alginat yang dihasilkan memberikan viskositas lebih tinggi dari Manutex $F$ (Alginat impor) dan memenuhi kriteria untuk proses pencapan yang dibuktikan dari hasil uji beda warna, whiteness index pada pencapan tanpa zat warna dan motif pencapan yang tajam (tidak migrasi). Alginat dari rumput laut coklat Garut, Serang dan Madura masing-masing memberikan viskositas $10.900 \mathrm{cps}, 13.060 \mathrm{cps}$ dan $9.780 \mathrm{cps}$, sedangkan Manutex $F 8.000 \mathrm{cps}$. Rendemen yang dihasilnya masing-masing 30,1\%, 28,4\% dan 24,2\%. Hasil uji hidrolisis parsial alginat menunjukkan bahwa blok guluronat (GG) dalam polimer alginat Garut, Madura dan Serang masing-masing 60,662\%, 50,274\%, dan 67,906\%. Hal ini berkaitan dengan sifat gel yang dibentuk. Alginat Serang cenderung lebih kaku dan kurang fleksibel dibandingkan dengan alginat Garut dan Madura.
\end{abstract}

Kata kunci: Alginat, rumput laut coklat, guluronat, zat warna alam.

ABSTRACT

Exploration pigments and alginates content from brown seaweed is intended for extracting pigment from brown seaweed and the residue was extracted alginate content for coloring silk fabric. Pigment extracted from brown seaweed was identified as acid mordant dye that gives natural color to produce dye on silk fabric with good value on color fastness to washing, rubbing, perspiration and light. Based on analysis of the functional groups of seaweed that has been extracted of their pigments showed that akginate content does not get carried away and can be further extracted.The resulting alginate thickener gives a higher viscosity than Manutex F (Alginate imports) and meet the criteria for a printing process, that is evident from the results of color different test, whiteness index on printing without dyes and gave sharp printing motifs (no migration). Alginates from brown seaweed of Garut, Serang and Madura gave a viscosity of 10,900 cps, $13060 \mathrm{cps}$ and $9780 \mathrm{cps}$, respectively, while Manutex $F$ was $8,000 \mathrm{cp}$, the rendement were $30.1 \%, 28.4 \%$ and $24.2 \%$. respectively. The test results of partial hydrolysis of alginate show that gulluronic block $(G G)$ in the alginate polymer of Garut, Madura and Serang were 60.662\%, $50.274 \%$ and $67.906 \%$. respectively. This relates to the nature of the gel formed. Alginate of Serang tend to be more rigid and less flexible than the alginate from Garut and Madura.

Keywords: Alginate, Brown Seaweed, gulluronate, natural dyes.

\section{PENDAHULUAN}

Hampir di seluruh perairan Indonesia tersebar sumber daya alam rumput laut coklat (Phaeophycea) yang sangat berpotensi dengan spesies yang beragam. Indonesia sebagian besar telah memenuhi kebutuhan rumput laut Internasional. Ekspor rumput laut ke beberapa negara hampir dipenuhi oleh Indonesia, namun kebutuhan Industri Tekstil terhadap alginat yaitu produk olahan hasil ekstraksi rumput laut coklat masih dipenuhi oleh impor terutama dari China, Taiwan, Jepang dan Korea. Pada Tabel 1 disajikan produksi rumput laut dan pertumbuhannya yang setiap tahun mengalami peningkatan. ${ }^{1}$

Sampai saat ini rumput laut yang dihasilkan dan di ekspor oleh Indonesia baru sebatas rumput laut kering/mentah dan baru sekitar 20\% yang dapat 
diserap dan diolah oleh industri dalam negeri. Indonesia masih mengimpor rumput laut dalam bentuk karagenan murni dan produk alginat dari rumput laut coklat. Indonesia masih mengimpor alginat 1100 ton per tahun. ${ }^{2}$

Tabel 1. Produksi rumput laut indonesia ${ }^{1}$

\begin{tabular}{ccc}
\hline Tahun & Produksi (ton) & Pertumbuhan (\%) \\
\hline 2006 & 1.374 .462 & - \\
2007 & 1.728 .475 & 24,10 \\
2008 & 2.145 .060 & 25,76 \\
2009 & 2.963 .556 & 31,28 \\
2010 & 3.906 .420 & 38,16 \\
$2014 *$ & 10.000 .000 & 156 \\
\hline
\end{tabular}

Sumber: Dirjen Perikanan Budidaya dan KKP,2011

Keterangan *)Target

Alginat terdapat secara alami dalam berbagai jenis rumput laut coklat. Alginat adalah polisakarida yang merupakan garam dari asam alginat, terdiri dari monomer (1-4)- $\beta$-D-asam manuronat (unit $\mathrm{M}$ ) dan $\alpha$-L-asam guluronat (unit G) yang bervariasi dalam jumlah dan distribusi sepanjang rantai polimernya. Dalam rantai polimer, dua unit ini dihubungkan pada posisi $(1 \rightarrow 4)$ dan menimbulkan blok homopolimer (MM dan GG) dan campurannya (blok MG bergantian). ${ }^{3,4}$ Panjang, distribusi dan perbandingan unit $\mathrm{M}$ dan $\mathrm{G}$ tergantung pada spesies rumput laut, umur tanaman dan bagian dari rumput laut (misalnya bagian batang atau daun). Hal ini menentukan sifat kimia dan fisika molekul alginat, yaitu blok GG cenderung mempunyai kapasitas pembentukan gel, blok MM dan MG mempunyai fleksibilitas pada rantai asam uronat dan fleksibilitasnya meningkat pada pembentukan rantai $\mathrm{GG}<\mathrm{MM}<\mathrm{MG}$. Urutan ini secara teoritis ditunjukkan oleh hambatan rotasi di sekitar ikatan glikosida dari polimer alginat. ${ }^{5,6,7}$

Alginat dapat dikarakterisasi dari derajat viskositasnya dalam bentuk larutan. Viskositas alginat dipengaruhi oleh kekuatan gel, konsentrasi alginat, derajat polimerisasi dan berat molekulnya. Faktor pembentukan gel alginat sebagai jaringan 3D makromolekul terjadi berdasarkan metode ikatan silang yaitu ikatan silang secara kimia melalui pembentukan ikatan kovalen atau secara fisik dengan ikatan silang antar rantai. Pembentukan gel fisik biasanya bersifat reversibel, berbeda dengan gel kimia yang tidak reversibel. Viskositas alginat juga dipengaruhi oleh suhu, kondisi asam dan perbandingan unit $\mathrm{M}$ dan $\mathrm{G}$ dari molekul alginat. Kategori viskositas alginat ditentukan dengan menggunakan larutan $1 \%(\mathrm{~b} / \mathrm{b})$ dari alginat pada suhu $20^{\circ} \mathrm{C}$. Klasifikasi tersebut adalah sebagai berikut: ${ }^{8}$
1. Viskositas tinggi : $600-1000 \mathrm{mPa} \cdot \mathrm{s}$
2. Viskositas medium : $200-600 \mathrm{mPa} \cdot \mathrm{s}$
3. Viskositas rendah : $20-200 \mathrm{mPa} \cdot \mathrm{s}$
Kategori tambahan seperti viskositas sangat tinggi $(>1000 \mathrm{mPa})$ atau viskositas sangat

rendah ( $<20 \mathrm{mPa})$ kadang-kadang digunakan untuk meng-gambarkan molekul alginat tertentu.

Peningkatan proporsi unit $\mathrm{G}$ menghasilkan bahan lebih kental. Perbandingan $\mathrm{M}$ dan $\mathrm{G}$ mempengaruhi laju pembentukan hidrogel dan/atau karakteristik akhir dari hidrogel. Alginat yang mengandung asam guluronat yang tinggi cenderung mempunyai struktur yang kaku (rigid) serta mempunyai porositas yang besar, sedangkan yang mengandung asam manuronat yang tinggi mempunyai struktur yang tidak kaku dan lebih fleksibel. ${ }^{6,9}$ Garam alginat dari $\mathrm{Na}$ dan $\mathrm{K}$ yang dihasilkan dari ion monovalen larut dalam air menghasilkan larutan kental yang tergantung pada ukuran polimer atau berat molekul, konsentrasi dan kekuatan ion dalam larutan. Alginat yang kaya akan asam manuronat akan diendapkan dan difraksinasi dalam medium kekuatan ion tinggi karena efek penggaraman. ${ }^{9,10}$

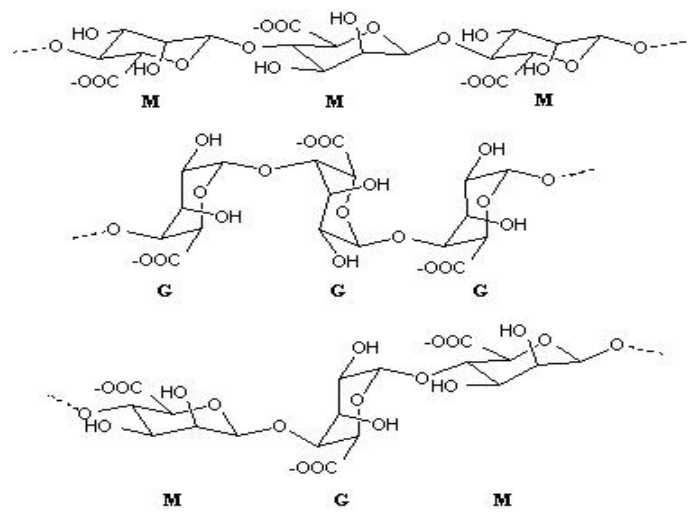

Gambar 1. Struktur molekul alginat pada beberapa tipe blok $\mathrm{M}$ dan $\mathrm{G}$

Beberapa jenis pigmen yang terkandung dalam rumput laut coklat antara lain fukosantin, klorofil, karoten dan mungkin masih terdapat jenis pigmen lainnya, namun fukosantin sangat dominan yang memberikan warna coklat tua hingga kuning coklat pada hasil celupan. Fukosantin adalah xanthophyll $\left(\mathrm{C}_{42} \mathrm{H}_{58} \mathrm{O}_{6}\right)$ berupa pigmen pada chloroplasts yang memberikan warna coklat atau hijau olive. Fukosantin mengabsorbsi cahaya primer untuk bagian warna biru-hijau sampai kuning-hijau dari spektrum tampak dengan variasi dan absorbsi secara signifikan disekitar panjang gelombang 400 - $500 \mathrm{~nm} .{ }^{11,12}$

Dengan memanfaatkan zat warna alam rumput laut coklat sekaligus kandungan alginatnya dimanfaatkan untuk pengental proses pencapan, diharapkan hasil penelitian ini membantu IKM untuk melakukannya secara mandiri.

\section{METODE}

Kadar alginat yang terkandung dalam setiap spesies berbeda-beda. Komposisi monomer dalam struktur polimer alginat merupakan salah satu 
Eksplorasi Kandungan Pigmen Dan Alginat Dari Rumput Laut Coklat Untuk Proses Pewarnaan Kain Sutera (Rifaida Eriningsih, dkk)

faktor yang menentukan kualitas alginat, oleh karena itu dalam penelitian ini dilakukan pada 3 jenis rumput laut coklat, yaitu yang berasal dari Pameungpeuk Garut (Sargassum crassifolium), Serang (Sargassum polycystum) dan Madura (Sargassum duplicatum) seperti tercantum pada Gambar 2.

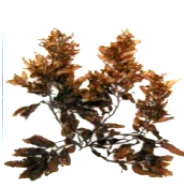

A

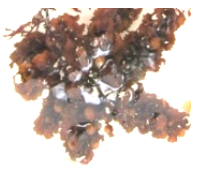

B

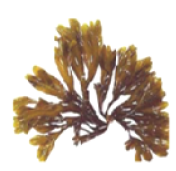

C
Gambar 2. Jenis rumput laut coklat (A: Garut, Sargassum crassifolium, B: Serang, Sargassum polycystum, C: Madura, Sargassum duplicatum)

\section{Bahan dan peralatan}

Rumput laut coklat 3 jenis, bahan kimia grade teknis untuk proses ekstraksi meliputi Natrium karbonat, kalsium klorida, Asam khorida, alkohol 70\%, hidrogen proksida serta bahan kimia grade p.a untuk analisis monomer alginat. Selain itu diperlukan zat warna reaktif, pengental Manutex $F$, kain sutera dan benang sutera.

Peralatan yang diperlukan meliputi peralatan untuk ekstraksi pigmen dan alginat, sedangkan peralatan uji yaitu Viscometer merek Brookfild, Fourier Transform Infrared Spectroscopy (FTIR) merek Shimadzu Prestige dan Spektrofotometer merek Shimadzu.

\section{Uji hidrolisis parsial alginat}

Komposisi komponen poliguluronat, polimanuronat dan segmen campuran antara manuronat dan guluronat.dalam alginat menentukan kualitas alginat. Untuk mengisolasi asam manuronat $(\mathrm{M})$ dan guluronat $(\mathrm{G})$ pada molekul alginat dilakukan dengan cara Hidrolisis Parsial Alginat, ${ }^{13}$ dengan cara:

- $\quad 5,00 \mathrm{~g}$ Alginat dalam $\mathrm{HCl} 0,3 \mathrm{~N}$ pada $100^{\circ} \mathrm{C}$ selama 2 jam diperoleh :

- fraksi yang larut diidentifikasi sebagai blok MG. Ikatan Hidroksil antara M dan G mudah terhidrolisis oleh asam

- fraksi tidak larut lebih tahan terhadap hidrolisis asam, kembali dilarutkan dengan menambah alkali dan difraksinasi dengan menyesuaikan $\mathrm{pH}$ pada 2.85, sehingga blok GG mengendap dan blok MM larut.

\section{Percobaan}

Percobaan dilakukan sesuai diagram alir pada Gambar 3.

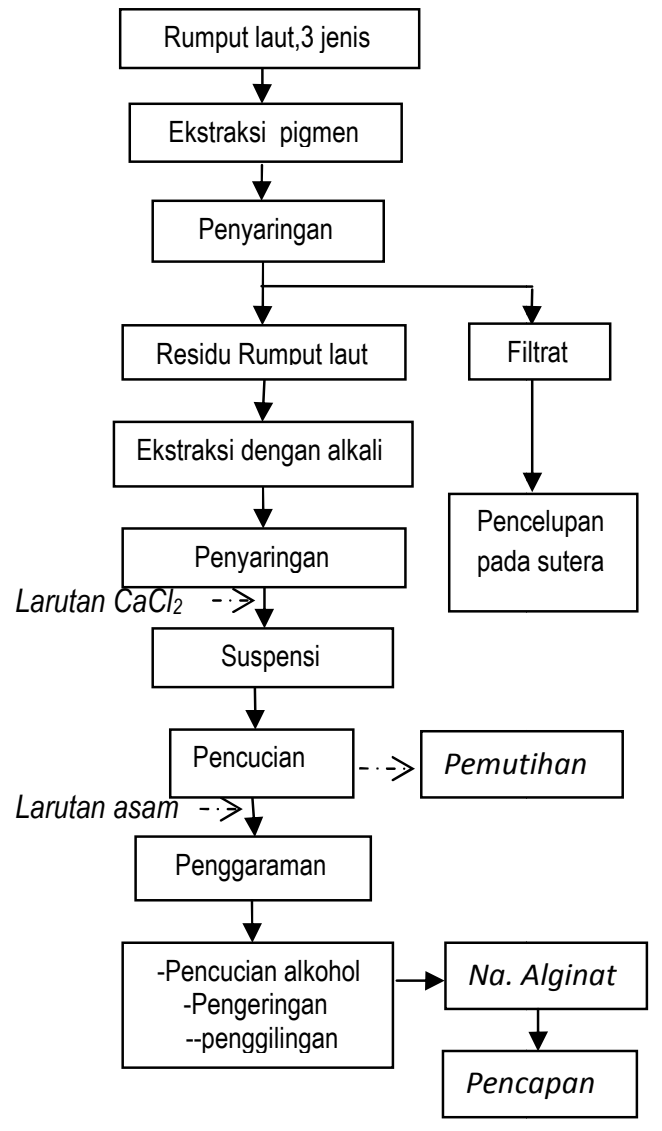

Gambar 3. Diagram alir percobaan

\section{HASIL DAN PEMBAHASAN}

\section{Ekstraksi pigmen rumput laut coklat}

Ekstraksi pigmen rumput laut coklat dilakukan dengan 2 cara yaitu perendaman rumput laut yang telah dicuci dan dirajang dalam air pada suhu kamar selama 2 hari atau diekstraksi dalam air pada suhu $100^{\circ} \mathrm{C}$ selama 2 jam. Hasil uji ekstrak pigmen dilakukan uji absorbansi warna pada pada cahaya primer dengan panjang gelombang 200-700 nm seperti disajikan pada Gambar 4. Pada Gambar menunjukkan bahwa pada panjang gelombang maksimum absorbsi warna pada ekstraksi suhu mendidih selama 2 jam $(\lambda$ maksimum $=351,07)$ yaitu $\mathrm{A}=4.2227$ lebih besar dibandingkan direndam 2 hari $(\lambda$ maksimum $=300.27$ ) yaitu $\mathrm{A}=3.5788$, Akan tetapi hasil celupan secara visual tidak memberikan perbedaan yang signifikan. Untuk aplikasi di IKM dapat dilakukan dengan direndam selama 1 hari untuk menghemat energi, selanjutnya dididihkan selama 15-30 menit.

Dari hasil identifikasi zat warna alam rumput laut coklat tersebut diketahui bahwa uji pewarnaan pada kapas menunjukkan hasil negatif, sedangkan pada wol dan sutera menunjukkan hasil positif. Berarti zat warna tersebut dapat digolongkan pada jenis zat warna ionik, yaitu zat warna mordan asam. 


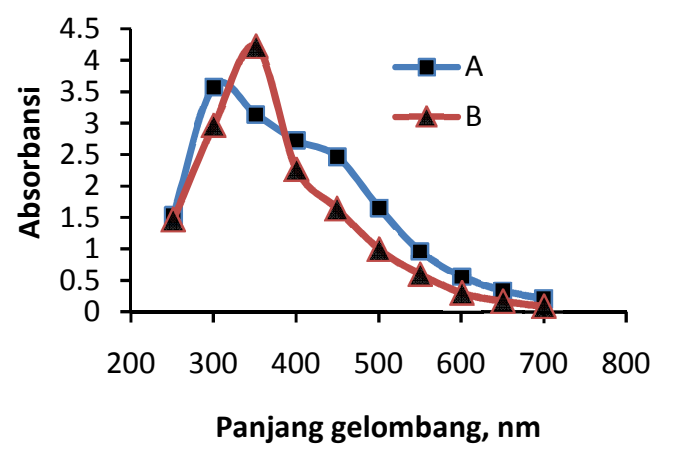

Gambar 4. Absorbansi cahaya primer pigmen rumput laut coklat (A: dalam air 2 hari, B: dalam air suhu $\left.100^{\circ} \mathrm{C}, 2 \mathrm{jam}\right)$

Hal ini disebabkan dalam ekstrak rumput laut coklat terkandung senyawa asam manuronat dan asam guluronat yang mempunyai gugus karboksil yang bersifat asam. Adapun serat - serat protein seperti sutera, wol mempunyai gugus amfoter (anionik dan kationik), sehingga zat warna yang bersifat ionik dapat berikatan secara elektrovalen dengan serat tersebut, seperti digambarkan sebagai berikut:

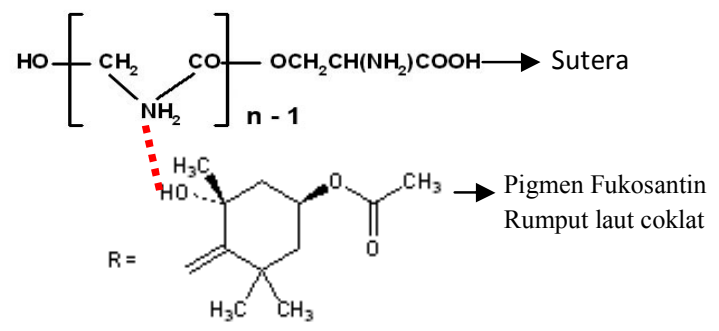

Gambar 5. Ikatan elektrovalen sutera dengan pigmen dari rumput laut coklat

Dari hasil celupan pigmen rumput laut coklat pada kain sutera telah dilakukan uji tahan luntur warna terhadap cuci, gosok dan keringat yang memberikan hasil sangat baik (nilai 4-5 pada skala Grey Scale maupun Staining Scale) setelah dilakukan kerja iring dengan tawas, tunjung (fero sulfat), campuran dengan kunyit dan campuran gambir. Sedangkan tahan sinar memberikan nilai relatif rendah sebelum dilakukan kerja iring yaitu 2-3 dan setelah kerja iring dengan tawas dan tunjung memberikan nilai 4 dan dengan kunyit serta gambir memberikan nilai 3 .

Hasil uji serapan gugus fungsi melalui kurva FTIR terhadap rumput laut coklat sebelum (awal = Ro) dan setelah diekstraksi pigmennya (R1) tercantum pada Gambar 6. Pada kurva Ro dan R1 terdapat puncak serapan pada bilangan gelombang yang sama yaitu pada $3429-3448 \mathrm{~cm}^{-1}$ dan 1608 $\mathrm{cm}^{-1}$ yang merupakan gugus karboksilat yang herdimer dalam struktur aloinat vano menuniukkan adanya ikatan hidrogen yang kuat. Gugus C-O serta $\mathrm{O}-\mathrm{H}$ juga ditunjukkan pada spektrum dari asam karboksilat disekitar bilangan gelombang $1411 \mathrm{~cm}^{-1}$ dan gugus $\mathrm{COOH}$ serta $-\mathrm{C}-\mathrm{O}-\mathrm{C}$ pada bilangan gelombang sekitar $1029.99 \mathrm{~cm}^{-1}-1093.64$ $\mathrm{cm}^{-1}$. Hal ini menunjukkan bahwa rumput laut coklat awal maupun setelah diekstrak pigmennya masih mengandung alginat yang ditunjukkan oleh adanya vibrasi hidroksil, karboksil, karbonil dan ikatan-ikatan antar karbon - $\mathrm{COOH}$ dan -C-O-C. ${ }^{4,13}$ Artimya alginat yang terkandung dalam rumput laut coklat dimungkinkan tidak terekstraksi pada saat pigmen warnanya diekstraksi.

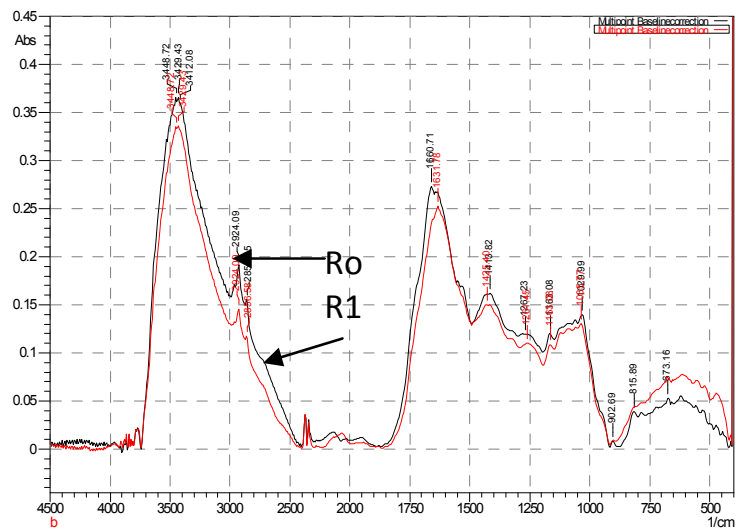

Keterangan :

Rumput laut awal (Ro), rumput laut setelah diekstrak pigmennya (R1)

Gambar 6. Kurva FTIR rumput laut coklat

\section{Ekstraksi alginat}

Residu rumput laut yang telah diekstrak pigmennya untuk pencelupan dilakukan ekstraksi dengan variasi natrium karbonat, dimaksudkan untuk mengekstrak kandungan alginatnya. Ekstraksi dilakukan terhadap rumput laut coklat Pameungpeuk Garut.

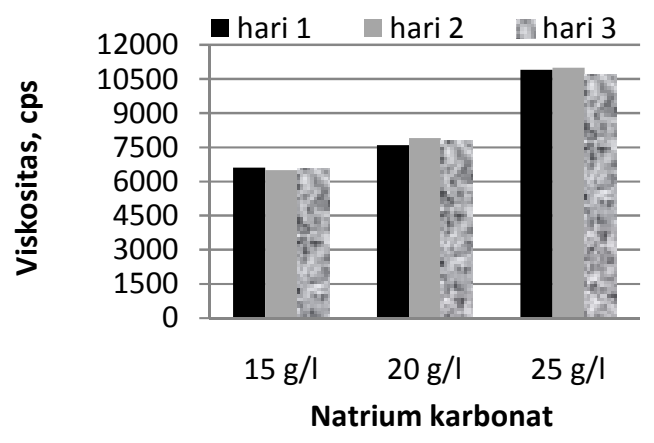

Gambar 7. Hasil uji viskositas alginat 5\% terhadap variasi konsentrasi natrium karbonat

Pada penggunaan natrium karbonat $25 \mathrm{~g} / 1$ menunjukkan viskositas relatif tinggi. Larutan Natrium Karbonat untuk mengekstraksi alginat dari rumput laut coklat dapat membantu proses nemuaian (nemhenokakan) iarinoan cel-cel aloa 

dkk)

yang mempermudah keluarnya alginat dari dalam jaringan alga. Selain itu dapat memisahkan protein dan selulosa dari jaringan, sehingga mempermudah proses ekstraksi alginat. ${ }^{6}$ Konsentrasi $\mathrm{Na}_{2} \mathrm{CO}_{3}$ berpengaruh terhadap rendemen natrium alginat yang dihasilkan. Semakin tinggi konsentrasi $\mathrm{Na}_{2} \mathrm{CO}_{3}$, maka rendemen yang dihasilkan juga semakin besar. Hal ini karena semakin banyak alginat terikat menjadi natrium alginat dari jaringan alga coklat, maka alginat yang terekstraksi akan semakin tinggi dan viskositasnya juga semakin tinggi. Dilakukan pula uji viskositas pada pengental alginat tersebut setelah disimpan 3 hari. Hal ini dilakukan karena biasanya pada proses pencapan di Perusahaan Tekstil pembuatan pengental untuk pencapan sekaligus untuk beberapa hari. Hasilnya menunjukkan pada hari ke 2 terjadi sedikit peningkatan dan hari ke 3 terjadi penurunan relatif kecil sekitar 1,5\%. Penyimpanan pengental alginat sampai 3 hari masih dapat digunakan dan belum terjadi pengenceran akibat mikroorganisme, namun harus dalam keadaan ditutup.

Proses pemucatan atau pemutihan dilakukan pada natrium alginat yang diekstraksi dari rumput laut coklat, dimaksudkan untuk memberikan warna tepung alginat tidak terlalu coklat. Pada Gambar 8 disajikan pengaruh pemucatan atau pemutihan setelah proses penggaraman (percobaan dilakukan pada rumput laut coklat Pameungpeuk Garut). Dari hasil uji tersebut terlihat bahwa semakin tinggi konsentrasi zat pemutih, viskositasnya semakin turun. Zat pemutih $\mathrm{NaOCl}$ ataupun hidrogen peroksida dapat mengoksidasi warna coklat dari alginat. Fukosantin dan pigmen lainnya yang masih terkandung dalam alginat akan mempengaruhi warna larutan. ${ }^{8}$ Selain itu warna coklat juga dipengaruhi oleh tipe alginofit. Warna setelah proses pemutihan berkisar kuning coklat hingga coklat .

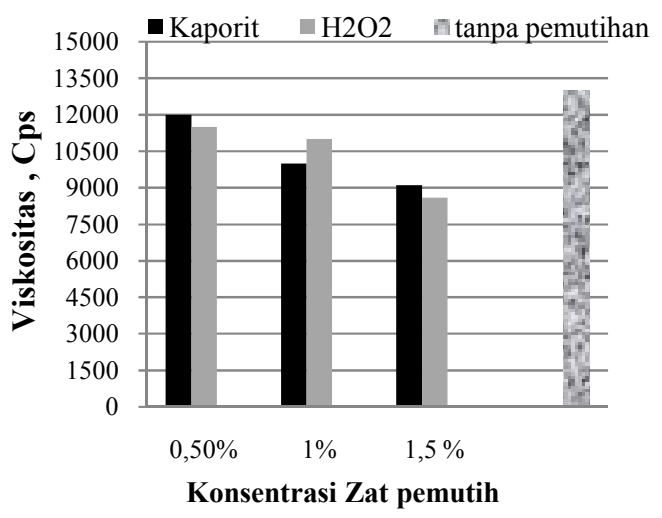

Gambar 8. Hasil uji viskositas terhadap variasi konsentrasi zat pemutih
Selanjutnya dilakukan ekstraksi terhadap rumput laut Madura dan Serang pada kondisi proses optimum yaitu pada penggunaan $\mathrm{Na}_{2} \mathrm{CO}_{3} 25 \mathrm{~g} / 1$ dan pemucatan dengan hidrogen peroksida $1 \%$. Penggunaan hidrogen peroksida $1 \%$ masih memberikan viskositas yang memenuhi persyaratan untuk proses pencapan. Hasil uji viskositas alginat pada konsentrasi $1 \%$ dan 5\% seperti disajikan pada Gambar 9. Dari data tersebut diketahui bahwa Alginat Serang menunjukkan viskositas tertinggi dan selanjutnya alginat Garut dan Madura. Ini juga dibuktikan dari hasil uji hidrolisis parsial alginat secara kuantitatif (Tabel 4) dan kurva FTIR secara kualitatif (Gambar 10). Menurut David J. M., viskositas alginat Garut, Madura maupun Serang termasuk pada viskositas medium. ${ }^{8}$

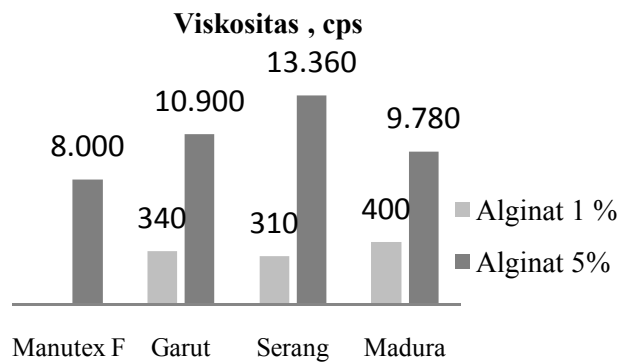

Gambar 9. Hasil uji viskositas terhadap ekstraksi beberapa jenis rumput laut coklat

\section{Hidrolisis parsial alginat}

Hasil isolasi asam manuronat (M) dan guluronat (G) pada molekul alginat dilakukan dengan cara Hidrolisis Parsial Alginat ${ }^{13}$, diperoleh endapan blok GG seperti tercantum pada Tabel 2, yaitu komponen $G$ tertinggi adalah alginat Serang dengan hasil uji viskositas yang relatif tinggi dan kaku, selanjutnya Garut dan terkecil Madura. Dengan demikian hasil uji ini sesuai dengan hasil uji viskositas seperti tercantum pada Gambar 9 dan hal inipun sesuai dengan hasil analisis gugus fungsi yang secara kualitatif dibuktikan pada kurva FTIR seperti disajikan pada Gambar 10.

Tabel 2. Hasil endapan blok GG pada struktur alginat

\begin{tabular}{cc}
\hline Jenis Rumput Laut & Blok GG \\
\hline Garut & $60,662 \%$ \\
Madura & 50,274 \\
Serang & 67,906 \\
\hline
\end{tabular}

Analisa gugus fungsi natrium alginat hasil ekstraksi rumput laut coklat

Serapan gugus-gugus fungsi dari ke tiga jenis rumput laut coklat tersebut seperti terlihat pada kurva FTIR Gambar 10 dan Tabel 3. 


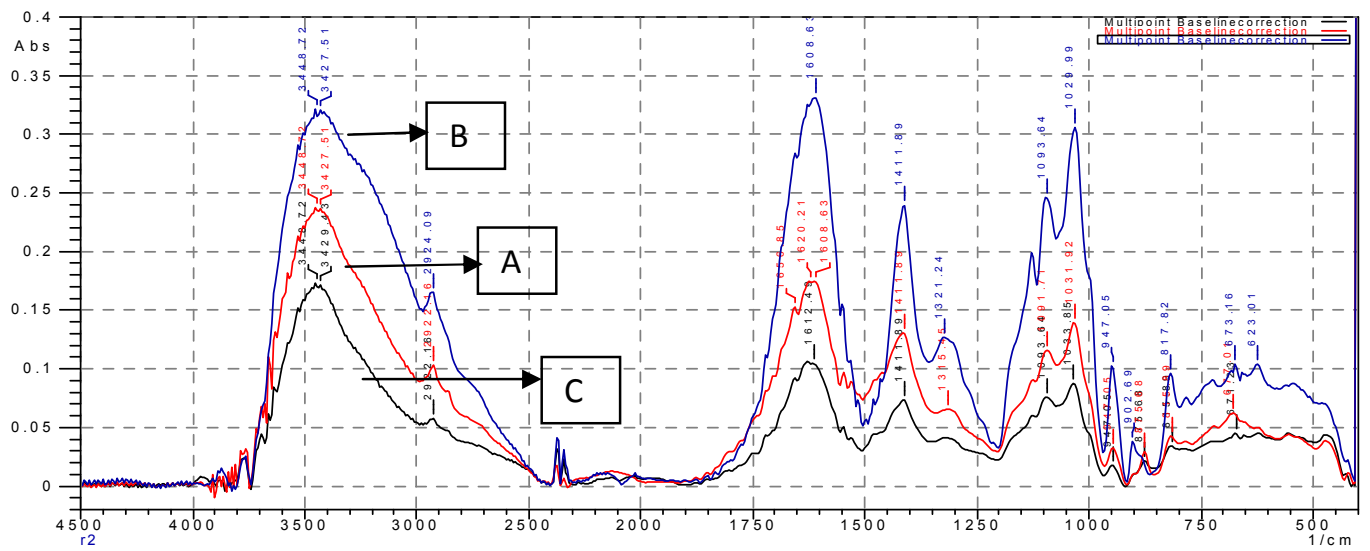

Keterangan : A: Alginat Garut, B: Alginat Madura, C: Alginat Serang

Gambar 10. Kurva FTIR Alginat

Spektrum natrium alginat menunjukkan adanya serapan gugus hidroksil $(-\mathrm{OH})$, gugus karbonil (-COO-), ikatan - $-\mathrm{OH}$ dan $-\mathrm{COOH}, \mathrm{C}-\mathrm{O}$ stretching, C-C stretching, dan C-O bending seperti terlihat pada Kurva FTIR (Gambar 10). Menurut Jesús Iván Murillo-Álvarez et al, ${ }^{13}$ serapan pada bilangan gelombang $1608.63 \mathrm{~cm}^{-1}, 1411.89 \mathrm{~cm}^{-1}$, dan $1091 \mathrm{~cm}^{-1}-1093.64 \mathrm{~cm}^{-1}$ (pada daerah bilangan gelombang $1608 \mathrm{~cm}^{-1}$ hingga $1091 \mathrm{~cm}^{-1}$ ), apabila lebih tinggi dibandingkan serapan pada bilangan gelombang $1029 \mathrm{~cm}^{-1}-1033 \mathrm{~cm}^{-1}, 947 \mathrm{~cm}^{-1}$ dan $817.82 \mathrm{~cm}^{-1}-875.68 \mathrm{~cm}^{-1}$ (pada daerah bilangan gelombang $1029 \mathrm{~cm}^{-1}$ hingga $817 \mathrm{~cm}^{-1}$ ) mengindikasikan bahwa polimer alginat terdiri dari proporsi monomer guluronat yang lebih tinggi. Sebaliknya serapan pada bilangan gelombang 1315 $\mathrm{cm}^{-1}, 1170 \mathrm{~cm}^{-1}, 1029 \mathrm{~cm}^{-1}-1033 \mathrm{~cm}^{-1}, 947 \mathrm{~cm}^{-1}$ dan $817.82 \mathrm{~cm}^{-1}-875.68 \mathrm{~cm}^{-1}$ lebih tinggi mengindikasikan bahwa polimer alginat terdiri dari proporsi monomer manuronat. Pada hasil kurva FTIR menunjukkan bahwa serapan pada bilangan gelombang $1608.63 \mathrm{~cm}^{-1}, 1411.89 \mathrm{~cm}^{-1}$, dan 1091 $\mathrm{cm}^{-1}-1093.64 \mathrm{~cm}^{-1}$ pada produk alginat Madura memberikan serapan lebih tinggi dibandingkan pada alginat Serang dan Garut, namun dari hasil uji endapan parsial blok GG (Tabel 2) menunjukkan gugus guluronatnya paling rendah $(50,274 \%)$. Hal ini kemungkinan pada bilangan gelombang $1029.99 \mathrm{~cm}^{-1}-1033.85 \mathrm{~cm}^{-1}$ memberikan serapan cukup tinggi, yaitu serapan C-O stretching dan C-O-C Stretching. Sedangkan produk alginat Serang dan Garut menunjukkan proporsi monomer guluronat yang lebih tinggi dibandingkan manuronat sesuai dengan hasil uji secara kuantitatif endapan parsial blok GG yaitu masing-masing $67,906 \%$ dan $60,662 \%$.

\section{Rendemen, kadar air, kadar abu, pH}

Hasil perhitungan rendemen alginat pada penggunaan natrium karbonat $25 \mathrm{~g} / 1$ dan peroksida $1 \%$ menuniukkan bahwa alginat Garut memberikan rendemen relatif tinggi yaitu $31,2 \%$, selanjutnya Madura 25,2\% dan Serang 21,6\% seperti terlihat pada Gambar 11. Kadar air alginat Garut, Serang dan Madura berkisar 15,4\%-16\%. Kandungan air dipengaruhi oleh kadar isopropanol atau alkohol yang digunakan untuk pencucian dan kemampuannya untuk mengikat air pada hasil penggaraman setelah proses ekstraksi rumput laut, sehingga dapat mengurangi kadat air. Kadar abu besarnya tergantung dari jenis rumput laut, kandungan garam mineral yang masih menempel pada permukaan rumput laut atau pada talus. ${ }^{14}$ Kondisi hidrologi dan hidrokimia dari rumput laut juga mempengaruhi besarnya kadar abu. Pada umumnya kadar abu dipengaruhi oleh komponen halogen ( $\mathrm{Br}$ dan I) yang terdapat pada garam mineral, ${ }^{6}$ yang tergantung pada proses pencucian awal sebelum ekstraksi. Nilai $\mathrm{pH}$ larutan alginat berkisar 7-8,6.

Tabel 3. Gugus fungsi pada kurva FTIR

\begin{tabular}{|c|c|c|c|c|}
\hline \multirow{2}{*}{$\begin{array}{c}\text { Bilangan } \\
\text { gelombang, } \\
\mathrm{cm}^{-1}\end{array}$} & \multicolumn{3}{|c|}{ Serapan (Abs) } & \multirow{2}{*}{ Gugus Fungsi } \\
\hline & Garut & Madura & Serang & \\
\hline $\begin{array}{c}3427.51- \\
3448.72\end{array}$ & $\begin{array}{c}0.237- \\
0.238\end{array}$ & 0.321 & 0.172 & $\begin{array}{l}\mathrm{O}-\mathrm{H} \text { stretching } \\
\text { Ikatan hidrogen } \\
\text { antar molekul }\end{array}$ \\
\hline 1608.63 & 0.174 & 0.331 & 0.105 & $\mathrm{C}=\mathrm{O}$ \\
\hline 1411.89 & 0.131 & 0.240 & 0.074 & ikatan $-\mathrm{C}-\mathrm{OH}$ \\
\hline $1091-1093.64$ & 0.116 & 0.247 & 0.076 & $\begin{array}{l}\mathrm{COOH}, \mathrm{C}-\mathrm{O} \\
\text { stretching } \\
\mathrm{C}-\mathrm{O}-\mathrm{C} \\
\text { stretching }\end{array}$ \\
\hline 1170 & 0.065 & 0.189 & 0.09 & $\begin{array}{l}\mathrm{C}-\mathrm{O} \text { stretching } \\
\mathrm{C}-\mathrm{C} \text { stretching } \\
\mathrm{C}-\mathrm{C}-\mathrm{C} \\
\text { bending }\end{array}$ \\
\hline $\begin{array}{c}1029.99- \\
1033.85\end{array}$ & 0.139 & 0.306 & 0.087 & $\begin{array}{l}\mathrm{C}-\mathrm{O} \text { stretching } \\
\mathrm{C}-\mathrm{O}-\mathrm{C} \\
\text { stretching }\end{array}$ \\
\hline 947.05 & 0.033 & 0.103 & 0.018 & $\begin{array}{l}\mathrm{C}-\mathrm{O} \text { stretching } \\
\mathrm{C}-\mathrm{C}-\mathrm{H} \\
\text { stretching }\end{array}$ \\
\hline $\begin{array}{c}817.82- \\
875.68\end{array}$ & 0.030 & 0.096 & 0.022 & $\begin{array}{l}\mathrm{C}-\mathrm{C} \text { stretching } \\
\mathrm{C}-\mathrm{C}-\mathrm{H} \\
\text { stretching } \\
\mathrm{C}-\mathrm{n} \text { handins }\end{array}$ \\
\hline
\end{tabular}




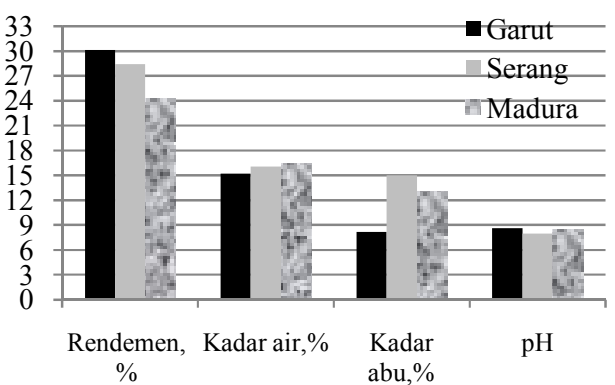

Gambar 11. Hasil uji rendemen alginat, kadar air dan kadar abu pada ekstraksi beberapa jenis rumput laut coklat

Proses pencapan zat warna reaktif menggunakan pengental alginat hasil ekstraksi

\section{Pencapan blangko (tanpa zat warna)}

Pencapan dilakukan dengan pengental alginat saja tanpa zat warna dan dilakukan fiksasi serta pencucian, dimaksudkan untuk mengetahui penodaan warna pengental pada kain. Secara visual warna kain tetap putih setelah dicuci, pengental mudah hilang, tidak menempel pada kain setelah pencucian dan tidak meninggalkan noda warna pada kain. Hasil uji derajat putih seperti disajikan pada Gambar 12, nilai whiteness index kain sutera blangko (tidak dicap) sebesar 64,3\%, setelah dilakukan pencapan dengan pengental alginat tetapi belum dicuci menunjukkan nilai 43,2\%, karena pengental masih menempel pada kain. Setelah kain diproses fiksasi dan pencucian nilai whiteness index kain terjadi penurunan yang relatif kecil yaitu dengan pengental alginat Garut dan Madura masing-masing sebesar $62,5 \%$ dan $60,4 \%$. Secara visual tidak memberikan penodaan pada kain putih awal. Hal ini menunjukkan bahwa pengental alginat dapat berfungsi sebagai medium pasta cap dan menghantarkan zat warna terabsorpsi ke dalam serat, namun mudah dihilangkan setelah pencucian tanpa mempengaruhi warna kain.

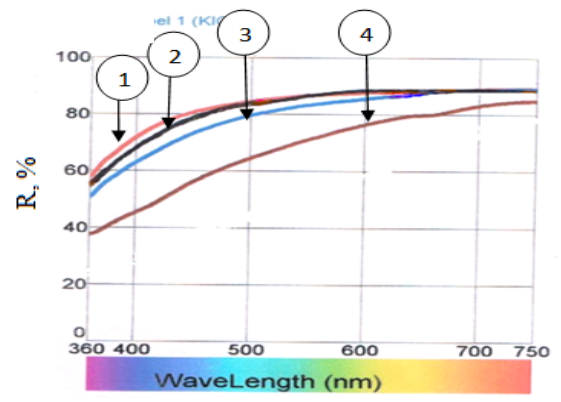

Keterangan :

Kain blangko, sebelum dicap (standar) : 1

Kain sutera setelah dicap, fiksasi dan cuci (Alginat Garut) : 2

Kain sutera setelah dicap, fiksasi dan cuci (Alginat Madura) : 3

Kain setelah dicap dengan pengental alginat, belum pencucian : 4

Gambar 12. Kurva CIE lab hasil uji derajat putih kain sutera setelah pencapan tanpa zat warna.
Pengental alginat yang disimpan hingga 4 hari masih menunjukkan hasil viskositas yang baik seperti terlihat pada Gambar 13 A, baik alginat Garut maupun Madura masih cukup baik dan fleksibel. Namun pada alginat Serang pengental semakin kental dan kaku, sehingga bila dicapkan pada kain akan terjadi retak. Hal ini kemungkinan karena dari hasil uji hidrolisis parsial alginat menunjukkan bahwa alginat Serang memiliki komponen guluronat cukup tinggi. Dengan demikian disarankan penyimpanan pengental alginat Serang tidak lebih dari 3 hari, karena akan mempengaruhi warna dan motif hasil pencapan yang berkemungkinan motif menjadi tidak tajam atau rusak dan berperngaruh pada efek kekakuan kain.

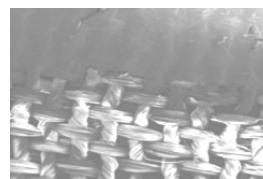

A

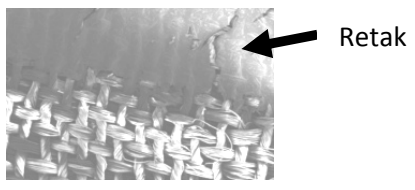

B
Gambar 13. Foto SEM pencapan pengental alginat setelah disimpan selama 4 hari. A: Alginat Garut, B: Alginat Serang

\section{Pencapan pada kain sutera}

Hasil pencapan pada kain sutera dengan zw. Reaktif berdasarkan uji CIE lab pada warna hasil pencapan tersebut terhadap standar (pengental Manutex F) disajikan pada Gambar 14.

Keteranlyaiı

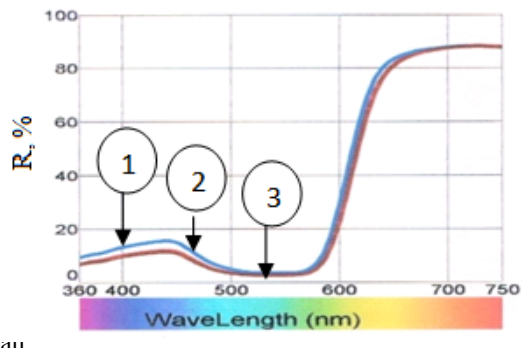

1: Pencapan dengan Alginat Madura

2 dan 3 : Pencapan dengan Alginat Garut dan pencapan dengan Manutex F/ standar, kurva berimpit

Gambar 14. Kurva CIE lab hasil pencapan dengan Pengental Alginat dan Manutex.

Dari hasil uji CIE lab pada warna hasil pencapan dengan alginat Madura dan Garut terhadap standar (pengental Manutex F) memberikan serapan gelombang yang secara signifikan sama dan dengan kurva yang terlihat hampir berimpit. Hasil beda warna $(\Delta \mathrm{E})$ masingmasing sebesar 1,09 dan 0,87 terhadap standar (Pengental Manutex F). Hal ini menunjukkan bahwa penggunaan alginat hasil ekstraksi rumput laut coklat tidak mempengaruhi dan tidak bereaksi dengan zat warna yang digunakan, dapat 
mengantarkan warna (merupakan media pasta cap), tidak mewarnai kain, dapat mengikat air, mencegah migrasi disekeliling motif, mudah dihilangkan dengan proses pencucian dan memberikan nilai warna yang baik.

\section{KESIMPULAN}

Ekstraksi pigmen rumput laut coklat dapat dimanfaatkan untuk zat warna alam dan residunya dapat diekstraksi kandungan alginatnya. Hasil pencelupan zat warna alam rumput laut coklat menunjukkan tahan luntur warna terhadap pencucian, gosokan, keringat dan sinar memberikan nilai baik, serta residu rumput lautnya masih dapat diekstrak kandungan alginatnya. Pengental alginat menghasilkan viskositas lebih tinggi dari Manutex $F$ (Alginat impor) dan memenuhi kriteria untuk proses pencapan. Alginat dari rumput laut coklat Garut, Serang dan Madura masing-masing memberikan viskositas $10.900 \mathrm{cps}, 13.060 \mathrm{cps}$ dan 9.780 cps, sedangkan Manutex $F \quad 8.000$ cps. Rendemen yang dihasilkan masing-masing 30,1\%, $28,4 \%$ dan $24,2 \%$. Hasil uji hidrolisis parsial alginat menunjukkan bahwa komponen blok GG dalam polimer alginat Garut, Madura dan Serang masingmasing $60,662 \%, 50,274 \%$, dan $67,906 \%$. Hal ini berkaitan dengan sifat gel yang dibentuk. Alginat yang mengandung asam guluronat yang tinggi cenderung mempunyai struktur kaku (rigid) serta mempunyai porositas yang besar yang ditunjukkan pada alginat Serang, sedangkan alginat Garut dan Madura relatif lebih fleksibel dan tidak kaku.

\section{PUSTAKA}

${ }^{1}$ Tim INDEF (Institute For Development of Econiomics And Finance), Outlook Industry, (2012), Strategi Percepatan dan Perluasan Agroindustri, Kementerian Perindustrian, Jakarta

${ }^{2}$ Kadi, A. (2005). Beberapa catatan kehadiran marga Sargassum di perairan Indonesia, Warta Ekspor Kementerian Perdagangan Republik Indonesia, DJPEN/MJL/002/10/2011 Edisi Oktober, Oseana, Volume xxx, Nomor 4,:19-29

${ }^{3}$ Viswanathan, S. and Nallamuthu, T. (2014). Extraction of Sodium Alginate from Selected Seaweeds and Their Physiochemical and Biochemical Properties, International Journal of Innovative Research in Science, Engineering and Technology, Vol. 3, Issue 4, April, Copyright to IJIRSET www.ijirset.com 10998

${ }^{4}$ Kendall, W.F., Darrabie M.D., El-Shewy H.M., Opara E.C. (2004). Effect of Alginate Composition and Purity on Alginate Microspheres, Journal Microencapsul, Dec; 21(8):821-8.
${ }^{5}$ Mushollaeni W, (2011), The Physicochemical Characteristics Of Sodium Alginate From Indonesian Brown Seaweeds, Afr. J. Food Sci. Vol. 5(6), pp. 349-352, June, Available online http://www.academicjournals.org/ajfs ISSN 1996-0794 C2011 Academic Journals

6 Mandal, S., Kumar, S.S., Krishnamoorthy, B., Basu, S.K. (2010). Development and Evaluation of Calcium Alginate Beads Prepared by Sequential and Simultaneous Methods, Brazilian Journal of Pharmaceutical Sciences, Vol. 46 (4).

${ }^{7}$ Mooney, D.J., Kim, W.S. (2012). Tissue Engineering Using Injectable, Oxidized Alginate Hydrogels, WO 2013025763 A2.

${ }^{8}$ Rocha-Leão, M. H. (2008). Ca Alginate as Scaffold for Iron Oxide Nanoparticles Synthesis, Braz. J. Chem. Eng. Vol.25 (4).

9 Mooney, D.J., Kim, W.S. (2012). Tissue Engineering Using Injectable, Oxidized Alginate Hydrogels, WO2013025763A2.

${ }^{10}$ Ghadban, A, (2012), The Synthesis of Oligoalginate Derived Glycomonomers (Algimers) and Their Conventional and Reversible Addition Fragmentation Chain Transfer (RAFT) Polymerizations In Aqueous Solution, Thesis Docteur De L'université De Grenoble FrenchSpécialité : Science des polymères, 20 January

${ }^{11}$ Aline, M., Lima, F., Soldi, V. Borsali, R. (2009). Dynamic Light Scattering and Viscosimetry of Aqueous Solutions of Pectin, Sodium Alginate and Their Mixtures: Effects of Added Salt, Concentration, Counterions, Temperature and Chelating Agent, J. Braz. Chem. Soc. Vol.20 (9).

${ }^{12}$ Wang, W.J., Wang, G.C., Zhang, M., and Tseng, C.K. (2006). Isolation of Fucoxanthin from the Rhizoid of Laminaria japonica Aresch, $J$. Integrative Plant Biology, 47(8), 1009-1015.

${ }^{13}$ Yamamoto, K., Ishikawa, C., Katano, H., Yasumoto, T., and Mori, N. (2011). Fucoxanthin and Its Deacetylated Product, Fucoxanthinol, Induce Apoptosis of Primary Effusion Lymphomas. Cancer Letters, 300, 225-234.

${ }^{14}$ Álvarez, J.I.M. and Carmona, G.H. (2007). Monomer Composition and Sequence of Sodium Alginate Extracted at Pilot Plant Scale from Three Commercially Important Seaweeds From Mexico, J Appl Phycol 19, 545-548.

${ }^{15}$ Haryanti, A.M., Darmanti, S., and Izzati, M. (2008). Absorption Capacity and Water Storage in Various Sizes of Seagrass Gracilaria verrucosa as the Base Material of Organic Fertilizer, $J$. Bioma, 10,1-6. 